\title{
Chapman and Webster on Matrimony: The Poets and the Reformation of Ritual*
}

\author{
RICHARD F. HARDIN
}

The age of the Tudors and Stuarts is one of continuous rebellion in religious worship, as successive generations of Protestants broke with the vestments, ceremonies, and even sacraments of medieval Christianity. Especially important in these developments is the argument frequently voiced in Puritan attacks on orthodox worship, and just as frequently assumed, that the physical world is at best a feeble reminder, and more likely a pollutant, of the spiritual. William Perkins went so far as to correct St. Paul on this subject. Concerning the apostle's exhortation, "Glorifie God in your bodies and in your spirits" (I Cor. 6. 20), Perkins warned his readers,

\begin{abstract}
Yet there must be some distinction and difference observed. For primarily and properly God is worshipped in our spirits.... By the spirit, I understand the thought of the mind, the conscience, \& the affections of the heart. For in these is the first and principall seate of divine and spiritual worship. As for the bodie, it is but a secondarie instrument of the service of God. By this, we may discerne the vanitie of Popish religion. For it consists, for the most part, upon externall and bodily rites, gestures, and ceremonies borrowed partly from the Jews and partly from the heathen: whereas the true religion of the newe testament, hath but fewe prescribed ceremonies, and for the most part is divine and spirtuall. $^{1}$
\end{abstract}

Of the many corollaries to be drawn from this view of religion as a purely spiritual activity, one was the virtual secularization of marriage. The Church of England, to circumvent the technicality that sacraments had to be instituted by Christ, had described marriage as a "holy estate" (Art. 25). Elizabethan Puritans, dissatisfied with Anglican compromises on this and other points, resented the sacramental flavour of "holy estate," not to mention the traces of Catholic ritual that still remained in

* A version of this paper was presented at the English I Section of the 1976 Midwest Modern Language Association meeting. I wish to acknowledge a grant from the General Research Fund of the University of Kansas which assisted me in writing the paper. 
the wedding service: receiving the Eucharist at marriage, the use of the wedding ring, and the carnality implicit in the form of the vow, "With my body I thee worship." 2 Contrary to Hooker's opinion that "The band of wedlock hath always been more or less esteemed of as a thing religious and sacred," Perkins writes that "Marriage of it selfe is a thing indifferent, and the kingdome of God stands no more in it, then in meates and drinkes; and yet it is a state in it selfe, farre more excellent, then the condition of the single life." Later in the seventeenth century the belief that marriage was essentially a legal contract led to the short-lived reforms under Parliament whereby civil magistrates were allowed to perform marriages. ${ }^{3}$

It should come as no surprise that concern over the status of matrimony should be expressed in the literature of the two remarkable decades on either side of 1603 , for any sensitive mind would have recognized that the issue extended beyond the pale of the divines. If marriage was a sacrament, or at least "a thing religious and sacred," the sexual union was sealed by the hand of God. If it was a distinctively human, legal arrangement, then was there not a danger that it might be treated too casually? I would like to explore two literary responses to the problem, representing two opposing views on the sacramentality of marriage. In George Chapman's Hero and Leander and certain other works of this generation, a deep sense of ritual will not allow a break with the fundamentally medieval view that marriages are sacramental acts that allow man to transcend his fleshly world. Not until Webster's The Duchess of Malfi is there a marriage in English literature which, with unceremonial - indeed anti-ceremonial - dignity, seems to find a resolution akin to that of modern society on the religious question in marriage.

It is generally recognized that Chapman's Hero and Leander (1598) was written to temper if not displace the exuberant materialism and sensuality of Marlowe's poem. Nevertheless, the allegorical portrait of the goddess Ceremony in Chapman's first sestiad underscores the sensuousness of this thematic figure: "she was all presented to the sence" (3. 119). ${ }^{4}$ For this reason she leads Religion "in a chaine, compact of eares and eies" (3.116), a detail touching upon the much-discussed role of the senses, especially sight, in religion (3. 125-28). Two decades earlier the Puritan William Fulke had attacked the traditional argument for images in worship: "the eye advertiseth our common sense, our common sense informeth that this image is true, and profitable to salvation, and worthie of all honours. This may well be an idolaters reason, but surely a Christian mans faith is instructed by hearing, and not by seeing, blessed are they (saith Christ) which have believed and not seene." 5 However, Chapman's "icon" of Ceremony supports Hooker's idea that worship must be induced and cultivated through the senses: "For sith God him- 
self is invisible and cannot by us be discerned working, therefore when it seemeth good in the eyes of heavenly wisdom, that men for some special intent and purpose should take notice of his glorious presence, he giveth them some plain and sensible token whereby to know what they cannot see" (II, 235). Hooker's influence upon Chapman's concept of ceremony is discussed in the work of D.J. Gordon; ${ }^{6}$ but like other scholars Gordon has assumed too readily that Chapman is handling his topic according to some Continental iconographer (pp. 55-56). It seems clear that the poet has created her specifically to elucidate an issue of serious consequence in his society.

The announced purpose of Ceremony's visit is to condemn Leander for making love to Hero without marrying her. Fornication epitomizes the condition of "substance without rites" (3.147) - or, to anticipate a theme of the fifth sestiad, life without form. Indeed, form may be taken as the underlying theme of Chapman's poem, ${ }^{7}$ with Ceremony as its tutelary goddess. Deprived of form-imposing Ceremony (and her attendants, Devotion, Order, State, and Reverence, Society, and Memory) men would remain "vicious and melancholy." The list of her attendants indicates the need for ceremony in every realm of human activity, religious or secular.

In several passages Chapman implicitly condemns Puritan attacks on orthodox ritual. Ceremony holds a laurel rod, the symbol of learning and discipline,

To beate back Barbarisme and Avarice,

That followed, eating earth and excrement

And humane lims; and would make proud ascent

To seates of Gods, were Ceremonie slaine. (3. 138)

A familiar (quite unfounded) charge against Puritans was their antiintellectualism, ${ }^{8}$ here coupled with their seditious designs upon lawful authority. The claim that Puritans harboured Anabaptist tendencies to anarchy and democracy ${ }^{9}$ is indicated in the role of Ceremony as guardian of the social order: she "all estates of men distinguisheth" (3. 134). These parallels are continued in the fourth sestiad, when Hero, having sacrificed her priestly vows to private lust, is likened to the "singularitie" of the sectarian (see 4. 169, 192). Henceforward "her Religion should be Policie" (4. 178: compare Shakespeare's puritanical Malvolio vowing to "read politic authors"); she will no longer worship in the temple of Venus, for "Her chamber her Cathedrall church should be" (4. 180). Perhaps the most overt allusion to the self-directed, anti-ceremonial religion of Puritanism occurs a few lines later, in the contrast between Hero and "other Priests": 
O lovely Hero, nothing is thy sin,

Wayd with those faults that other Priests are in;

That having neither faiths, nor works, nor bewties,

T'engender any scuse for slubbered duties,

With as much countnance fill their holy chaires,

And sweat denouncements gainst prophane affayres,

As if their lives were cut out by their places,

And they the only fathers of the Graces. (4. 210)

Chapman's conservative religious sympathies are glimpsed in the claim that "works" and "bewties" are lacking in these ministers of "slubbered" (carelessly performed) worship. One recalls George Herbert's desire for a liturgy guided between the extremes of "superstition," the Catholic excess, and "slovenliness," the Puritan defect. ${ }^{10}$ The last three lines, I think, describe the use of the pulpit by some of the more radical Protestants to rail against political authority ("prophane affayres") and the arts, especially dancing and the theatre ("the Graces").

Chapman's poem is rightly described by C.S. Lewis as "a eulogy of marriage,"11 but the philosophical basis for this eulogy is the need for ritual in all significant undertakings. Most profoundly the notion is expressed in the statement that "where Loves forme is, love is, love is forme" (5. 227). It is a point of view widely shared by poets of the age: one might point to the symbolism of union between earth and heaven in Jonson's wedding masque Hymenaei (1606) or the wedding masque of Juno, Iris, and Ceres in The Tempest, where Iris represents the bridge or transcendence between earth (Ceres) and heaven (Juno). These authors seem to have understood marriage as sacramental not so much in the doctrinal sense (that is, as an act instituted by Christ to give grace) as in the Roman sense of sacramentum, a vow or pact - between the two participants, between God and the married couple, between the natural and divine orders as a whole. Leander's violation of ceremony is parallelled by Hero's breaking her vow of chastity. Vows are likened to rituals - or perhaps it would be more nearly correct to say that a ritual is a form of vow. When Chapman has Hero officiate at the marriage of Mya (from Greek mueo, to be initiated into mysteries), a handmaid whom the priestess has absolved from her vow of chastity, he makes the point that vows and ritual alike become trivial things once violated:

yet faire Hero now

Intended to dispence with her [i.e., Mya's] cold vow,

Since hers was broken, and to marrie her:

The rites would pleasing matter minister

To her conceits, and shorten tedious day. (5.37)

It is for this dubious ceremony that Teras (the Greek word for sign, 
portent, or wonder) appears and relates the story of Hymen and Eucharis, whose marriage points up the contrast with the one at which Hero officiates. Thus after the story, when Teras turns her back on the bride and groom, the sight of her darkness "Made them all shriek, it lookt so ghastly black" (5.490). In other words the ominous prophetess anticipates the retribution for lust in telling a tale that exalts heavenly love.

The eradication of barbarism by ritual is effected in Teras's story itself (5.91-426). The two lovers with their companions are on their way to "doe great Ceres Eleusinian rites" when captured by pirates, "Barbarous rovers" with "rude hands." Hymen's slaughter of the pirates in the cave symbolizes the civilized man or man of grace (to most Elizabethans they are the same) overcoming the unruly instincts. Eucharis represents grace on several counts: she and her maids are likened to the firmament outside the cave $(5.173,311)$; she is reputed as wealthy beyond Hymen's deserts (5. 123); and her name is of course associated with the sacrament. Unlike the imperfect love of Hero and Leander, the union of Hymen and Eucharis represents that of natural or physical beauty and goodness with heavenly love or grace. The wedding occurs in the Temple of Juno, not that of Venus where the tale is being told, and so ritualistic is the marriage service that words seem out of place:

Nothing they spake, for twas esteemed too plaine

For the most silken mildnes of a maid,

To let a publique audience heare it said

She boldly tooke the man .... (5.370)

The boldness of the profane lovers, Hero and Marlowe's "bold, sharpe Sophister" Leander (1.197), contrasts with the image of the modest couple in Teras's tale, somewhat as the enamelled brilliance of Marlowe is set off by the cool reserve of Chapman's ritualistic imagination.

In Webster's Duchess of Malfi, probably written fourteen years after Chapman's poem, there is little of the orthodox sentiment regarding rites or the rites of marriage. The Duchess's great indiscretion in arranging a private marriage with her steward must be measured against the unspeakable cruelty of her brother in later arranging secret rites of mental torture and execution. Both events are explicitly labeled as abuses of ceremony, ${ }^{12}$ in that the characters perform in private what ought to be done with public knowledge. We are asked to consider whether the casual, unministered marriage of a prince to a social inferior is categorically different from the execution of a prince without public knowledge. In either case, ceremony is conventionally supposed to be the sign of divine sanction, and the neglect of ceremony attests the barbarism - to use Chapman's term - of this society.

This approach to the play resembles that in James Calderwood's 
excellent essay, ${ }^{13}$ except that Calderwood does not examine his subject in light of the current religious controversies. My only serious disagreement is with his assumption that this play is purely mimetic drama. The claim is that "Webster is using ceremony as a dramatic device to explore subtleties of character and action" (p. 283); but could it not equally be said that he employs character and action to explore the implications of certain ideas? And in view of Webster's generally acknowledged satiric inclinations, the influence of the intellectual Chapman, and the muchdeplored sacrifice of dramatic dialogue to ideas cribbed from commonplace books, ${ }^{14}$ might it not be possible to approach this play as an illustrative or symbolic work like Hero and Leander?

Catholic Italy, both in this play and The White Devil, seems to be a land under demonic possession, where the spiritual truth of the adage homo homini lupus is borne out in the physical lycanthropy of Ferdinand during the last act. Ceremony should, as Calderwood says, be "in the service of supra-individual interests" (p. 281); but that is obviously not the case in this play, where the evil brothers hold sway. Puritan objections to ceremonies were directed against precisely those supra-individual interests. In assenting to rituals promulgated by "papal idolatry" the worshipper, whether he knew it or not, was cooperating with the work of Satan. The Duchess's dilemma is that her marriage cries out for the legitimization that only ceremony can provide, but that such recognition would lead inexorably to her and Antonio's destruction by the brothers. The repeated animal imagery in the play only reminds us that no rites or vestments can conceal the essential bestiality of man.

This dilemma centers on a profound question about the human predicament, as seen in a broadly Calvinist (not exclusively Puritan) perspective. The material world is evil, but we must live in it. In terms of the vestarian controversy, Bosola voices the pessimistic side of the matter: "though continually we bear about us/A rotten and dead body, we delight/To hide it in rich tissue" (II. 1. 60). He has a personal, philosophical interest in the Duchess's ordeal, for if he can prove that she is merely "a box of worm-seed" (IV. 2. 123) his self-serving materialism will be justified. The effect of her admirable reply - "I am the Duchess of Malfi still" - is a reminder that honour and virtue can exist without ceremonial trappings, those externals of "painted honour" that Bosola himself casts off when renouncing his past. The Duchess, then, has a curiously modern existential dignity in facing death. Having rebelled against the dubious conventions of the Court and Church, she secures her own salvation through love and personal honesty. This rebellion against convention was parallelled in Webster's society by the Puritan drive to strip religious worship of all its externals, exposing the soul exclusively to the light of the Word. The unceremonious "private" marriage 
is justified in that all ceremonial acts in this play are charged with deceit. The pilgrimage to Loreto culminates in the Cardinal's specious resignation; Julia (entirely Webster's invention) dies after swearing "most religiously" and kissing the book; Ferdinand conceives of his sister's torture as an ironic ceremony involving "masques of common curtizans" (IV. 1. 149).

As Antonio goes to meet his death he pauses at a ruined abbey in a scene redolent of the Jacobean melancholy, the funereal tones of Browne and the later Donne. The echo of the cloister wall is a "deadly accent," a "thing of sorrow," because it cannot affirm the wished-for tie between humanity and heaven at this dark moment in the play. If the echo is intended as a warning to Antonio from beyond the grave, it falls on deaf ears: "Eccho, I will not talk with thee,/For thou art a dead thing" (V. 3. 49). The symbol of the echo underscores the impossibility of any resonance between the natural or social, and supernatural orders: man in his beastliness imitates the worst of nature, his society being separated from God by an impenetrable curtain of sin. Antonio concludes, "But all things have their end:/Churches and Citties, (which have diseases like to men)/Must have like death that we have" (V. 3. 18). This just escapes being a Renaissance commonplace in the inclusion of "churches," for The Duchess is a tragedy of religion as well as state. The decayed abbey and the corruption of the ceremonious Cardinal are both instances of the taint of mutability in human worship. Surrounded as they were by ruined abbeys, cathedrals, fallen monuments of medieval Christianity, Webster's audience could not help but agree - even to the extent that its own church might one day follow suit. The sense of a world abandoned by God underlies, I believe, the ambiguity of Bosola's last speech: "We are onely like dead wals or vaulted graves,/That ruin'd, yeilds no eccho" (V. 5. 121). Although the ruined abbey did yield an echo, it was unattended, as if humanity had in its own hopelessness destroyed the bridge between earth and heaven.

Acknowledging the infirmity of the natural and social order, Webster's tragedy endures rather than accepts the prospect of a life devoid of ceremony, especially of that which is most influential in most human lives, the rite of marriage. The orthodox Chapman's allegory had put the question of ceremony to the acid test: to abandon it is to abandon the ordering of life, including sexual life, which must ultimately mean to elect for barbarism. But throughout this period one always hears the voices of orthodoxy resorting to the argument of order: "Let all things be done decently and in order," in the words of the favorite Anglican text on liturgy (I Cor. 14.40). William Covell appeals to the "comeliness of order" in reply to the Puritan Josias Nicholls. "For seeing order is the ornament of all Societies, and seeing the Church, of all Societies, is 


\section{2 / Renaissance and Reformation}

most excellent, it must needes follow, that those things which (Civilie done) doe adorne others, uncivilie neglected, or contemned, doe disgrace the church."15 It will be recalled that Hooker's defense of the English church begins with an awesome account of the need for order in nature, society, and church. ${ }^{16}$ The prelatical treatises of the 1590's seem so obsessed with order and authority that the real concerns of the Puritans are often left unanswered (see especially the writings of Bishop Bancroft in this regard).

Prominent among these concerns was the belief that orthodox prescriptions were leading people into idolatry - "For when men set up a devised worship, they also set up a devised God." 17 It is difficult to place this idea on any evolutionary scale of religion, for if it savours of a reactionary fundamentalism it also looks forward to the distinctively personal emphasis of theology in our time. Eventually conservatives like Jeremy Taylor might complain of the new Puritan prayer book of 1644 that it "joins in marriage as Cacus did his oxen, in rude, unform, and unhallowed yokes"; ${ }^{18}$ but it might at least be said that the Puritan approach took into unprecedented account the limitations of mortal men and women. Underlying the marriage of Hymen and Eucharis in Hero and Leander is the belief that in certain ways men can be made divine, which is another way of saying that in certain ways God is like us. Chapman's Platonism, like that of Spenser and other Renaissance poets, often shows that tendency of the primitive religious mind which Owen Barfield has called "original participation" - "the sense that there stands behind the phenomena, and on the other side of them from man, a represented, which is of the same nature as man." 19 The Puritans, on the other hand - like Webster's Bosola, and perhaps the Duchess herself - implicitly understood the hypocrisy of rich tissue. Positing a religion wholly of spirit and word, they furthered the division between inner and outer man which has so concerned Barfield, Eliot, and others in our time. As the most sensitive minds of that age realized, the now seemingly narrow liturgical opinions of Puritans were challenging an entire world view. It is neither anachronistic nor ingenuous to say that the desacralization of marriage was one stage in a revolution: "The great revolutions," as Camus has said, "are always metaphysical."

University of Kansas

Notes

1 A Warning against the Idolatrie of the Last Times (Cambridge, 1601), pp. 189-90. The S.T.C. lists one, but there are at least two octavo editions of 1601 , both in the Cambridge University Library. I use the one containing 276 numbered pages. 
2 For a convenient epitome of Whitgift's and Cartwright's views on these subjects, see notes to Richard Hooker, Of the Laws of Ecclesiastical Polity, Everyman Library (London: Dent, 1968), II, 392-97.

3 Hooker, ed. cit., II, 391; Perkins, Christian Oeconomie (1590), transl. T. Pickering (1609), rpt. Works (Cambridge, 1618), p. 671; Reginald Haw, The State of Matrimony (London: S.P.C.K., 1952), p. 65. Although civil marriages remained the exception in England after the Restoration, weddings were secularized to the extent that it was rare for a couple to receive the Sacrament (Hooker, II, 397, n.). In New England, only civil magistrates performed marriages until conformity was imposed in 1686: see Edmund Morgan, The Puritan Family (1944; rpt. New York: Harper and Row, 1966), p. 32.

4 I use the text in Elizabethan Minor Epics, ed. Elizabeth S. Donno (New York: Columbia Univ. Press, 1963).

5 D. Heskins. . Overthrowne (1579), p. 613. On the eye and ear, see William G. Madsen, From Shadowy Types to Truth (New Haven: Yale Univ. Press, 1968).

6 “Chapman's 'Hero and Leander,"” English Miscellany, 5 (1954), 41-92.

7 The meaning of form is analyzed by Gordon (see n. 6), and more fully by Raymond Waddington, The Mind's Empire: Myth and Form in George Chapman's Narrative Poems (Baltimore: Johns Hopkins Univ. Press, 1974), pp. 161-80, with an emphasis on the occult learning in this poem rather than its social applications.

8 Oliver Ormerod, The Picture of a Puritane (1605), says that Puritans believe "that all Gentile learning should be abandoned from the lips of Christians" (p. 63).

9 Cf. David Owen, Herod and Pilate Reconciled (1610), pp. 47-54; Ormerod, p. 17; Richard Bancroft, Dangerous Positions and Proceedings (1593), passim.

10 A Priest to the Temple (Chap. 13), in The Works of George Herbert, ed. F.E. Hutchinson (Oxford: Clarendon Press, 1941), p. 246.

11 English Literature in the Sixteenth Century excluding Drama (London: Oxford Univ. Press, 1954), p. 515.

12 See The Duchess of Malfi, ed. F.L. Lucas (London: Chatto and Windus, 1958), I. 1. 358 : "Such weddings may more properly be said/To be executed, then celebrated." Also IV. 2. 322: "Did any ceremoniall forme of Law,/Doombe her to not-Being?"

13 "The Duchess of Malfi: Styles of Ceremony," Essays in Criticism, 12 (1962); rpt. in Shakespeare's Contemporaries, second edition, ed. Max Bluestone and Norman Rabkin (Englewood Cliffs, N.J.: Prentice Hall, 1970), pp. 278-88.

14 R.W. Dent, John Webster's Borrowings (Berkeley and Los Angeles: Univ. of California Press, 1960).

15 A Modest and Reasonable Examination (1604), p. 61.

16 For W.D.J. Cargill Thompson the threat to order is a red herring in Hooker's anti-Puritan strategy, especially redolent in Hooker's preface: "The Philosopher of the 'Politic Society': Richard Hooker as a Political Thinker," in W. Speed Hill, ed., Studies in Richard Hooker (Cleveland: Press of Case Western Reserve Univ., 1972), p. 14.

17 Perkins, Warning against Idolatrie, p. 15.

18 An Apology for Authorized and Set Forms of Liturgy, in The Whole Works of the Right Rev. Jeremy Taylor, ed. R. Heber, rev. and corr. C.P. Eden (London: Longmans Green et al., 1893), V, 253.

19 Saving the Appearances: A Study in Idolatry (New York: Harcourt, Brace and World, 1965), p. 111. 